\title{
Człowiek i przyroda w nauce chrześcijańskiego Wschodu
}

\begin{abstract}
Wstęp
We współczesnej literaturze filozoficznej i teologicznej widzimy wzrost zainteresowania środowiskiem naturalnym, w którym żyje człowiek. Coraz częściej, szczególnie w teologii, zwraca się uwagę na to, że wszechświat również oczekuje wypełnienia się dziejów zbawienia i wyzwolenia $z$ obciążenia grzechem. Stworzenie żyje $w$ nadziei, że ono również "zostanie wyzwolone $z$ niewoli zepsucia, by uczestniczyć w wolności i chwale dzieci Bożych" ( $\mathrm{Rz} 8,21)$. Stworzenie jednak nie samo popadło $w$ tę niewolę. Stało się tak za sprawą człowieka, który, jak piszą ojcowie Kościoła, reasumuje w sobie to, co widzialne - materialne i to, co niewidzialne - duchowe. Coraz częściej współcześni teologowie podkreślają współzależność losów człowieka i kosmosu ${ }^{1}$. Człowiek związany jest z resztą stworzenia potrójnym węzłem. Po pierwsze jest to związek wynikający ze wspólnego początku; zarówno człowiek, jak reszta stworzenia, powstał "z niczego"(ex nihilo) i został stworzony przez Boga. Po drugie owa jedność wyraża się w tym, że wszystko podlega określonym prawom zmienności i przemijania. Człowiek nie jest od tych praw wolny. Trzeci aspekt jedności to wspólne powołanie do rozwoju ukierunkowanego na wspólny cel, jakim jest wypełnienie historii wszelkiego stworzenia $w$ Bogu ${ }^{2}$. Do czołowych teologów katolickich reprezentujących takie ujęcie teologii można zaliczyć W. Hryniewicza i R. E. Rogowskiego a wśród teologów zagranicznych na pierwszy plan wysuwają się K. Rahner i H. U. Balthasar ${ }^{3}$, a także T. Śpidlik. Jest to temat nowy i stary zarazem. Był on obecny już w myśli Ojców Kościoła, głównie wschodnich, ta-

\footnotetext{
Diecezja Łomżyńska.

E. KOTKOWSKA, Pomyśleć świat jako catość wedlug św: Grzegorza z Nyssy, Poznań 2003, s. 11. i Człowiek", ComP - Kolekcja 49 1998), s. 31-42.
}

2 M. LECLERC, Potrójna jedność świata fizycznego, thum. M. Tryc-Ostrowska, w: „Kosmos

3 E. KOTKOWSKA, Pomyśleć świat jako catość wedtug św. Grzegorza z Nyssy, s. 11-12.
\end{abstract}


kich jak Grzegorz z Nyssy, Maksym Wyznawca czy Cyryl Jerozolimski, a także u teologów Wschodu dawniejszych i współczesnych.

Do współczesnych teologów, czerpiących z nauki wschodnich Ojców Kościoła, zajmujących się ukazywaniem ścisłego związku między człowiekiem, a resztą świata stworzonego, należy niewątpliwie zaliczyć $O$. Clément. Zajmuje się on ukazywaniem człowieka $w$ relacji do Boga i innych ludzi, ale drogim jest mu również temat dotyczący stosunku człowieka do wszechświata. Niniejszy artykuł poświęcony będzie głównie ukazaniu myśli tego francuskiego teologa na zarysowany powyżej temat. Tematem tym zajmują się zarówno filozofia, teologia, jak i nauki przyrodnicze. Nie jest on spoza obszaru antropologii, przeciwnie należy do niej integralnie ${ }^{4}$. Wszak człowiek, jak uczy Biblia, jest ukoronowaniem stworzenia i otrzymał od Boga świat w swe władanie ( $\operatorname{Rdz} 1,28)$. Uczy Sobór Watykański II: „Wszystko Bóg stworzył dla człowieka, a tylko jego samego pragnął ze względu na niego samego" (KDK, nr 24). Bez uwzględnienia relacji człowieka do świata, wiedza o samym człowieku byłaby niepełna ${ }^{5}$.

\section{Tajemnica bytów stworzonych}

W dzisiejszym świecie - pisze O. Clément - ci, którzy nic nie wiedzą o Bogu, a jest ich wielu, mają przeczucie Boga poprzez stworzenia, kiedy je oglądają $w$ ich $w$ autonomii, pięknie i harmonii. Odczuwaja oni Boga wtedy, kiedy doznają zachwytu $z$ tego powodu, że rzeczy istnieją ${ }^{6}$ Kosmos - słowo, które u starożytnych Greków oznaczało jednocześnie porządek i ornament, potwierdza fakt, że $z$ chaosu wydobywa się harmonia, a ze śmierci - życie jako jej przeciwieństwo ${ }^{7}$. Sprawia to Mądrość Boża, którą człowiek rozszyfrowuje przez swoją mądrość, poprzez tzw. „celebrację naukową" . „Albowiem - jak pisze św. Paweł - od stworzenia świata niewidzialne Jego (Boga) przymioty - wiekuista Jego potęga oraz Bóstwo - stają się widzialne dla umysłu przez Jego dzieła [...]" $(\mathrm{Rz} 1,20)^{9}$.

Inny współczesny teolog prawosławny D. Staniloaë w swojej Teologii dogmatycznej podkreśla fakt, iż sama racjonalność świata bylaby niewytłumaczalna bez odwiecznego Podmiotu. Zakłada ona istnienie "głębi rozumnej", a nawet więcej niż rozumnej, apofatycznej, odwiecznej Osoby i

\footnotetext{
Zob. J. APTACY, Antropologia Oliviera Clément, Olecko 2004, s. 131.

Tamże, s. 131.

O. CLÉMENT, Alle fonti con i Padri. I mistici cristiani delle origini. Testi e commento, Roma 1987, s. 209.

7 Tamże, s. 209

Tamze, s. 210

9 Zob. też: Mdr 13, 1-9.
} 
ma sens tylko wtedy, gdy zostanie sfinalizowana przez tę Osobę - Początek, Stwórcę i przez inne osoby - ludzi, aby uaktualnić z nimi "harmonię i komunię miłości"10. Nie chodzi tu tylko o pewną teologię naturalną, ale o pierwsze objawienie, o przymierze z Logosem „,[..] w którym zostało wszystko stworzone: i to, co w niebiosach, i to, co na ziemi, byty widzialne i niewidzialne [...]" (Kol 1, 16); przymierze odnowione i cudownie zgłębione przez Wcielenie tegoż Logosa ${ }^{11}$.

O. Clément pisze, że kiedy mówi się o relacji między człowiekiem a kosmosem, w rachubę wchodzą dwie postawy czlowieka: pozostającego na zewnątrz rzeczywistości, która jawi się jego oczom, lub włączonego w rzeczywistość, którą postrzega jako organiczną wszechjedność. Pierwsza postawa dała początek starożytnej "fizyce", nauce o rerum natura ${ }^{12}$. Wiedza ta, już uduchowiona, stała się u ojców Kościoła theoria physiké, „kontemplacją naturalną"13. Wprawdzie Grecy opracowali zasady tej modlitwy kosmicznej, ale praktykowali ją w niewielkim stopniu z powodu cech swego intelektu. Bardziej, bowiem medytowali nad "natura”" kosmosu jako takiego niż nad konkretnym kosmosem. Inaczej było u wielu ascetów rosyjskich ${ }^{14}$. Archimandryta Prokofiusz Koropcew z Monasteru Mitrofana w Woroneżu napisał rozprawę, którą zakończył słowami: „Nie ma wątpliwości, że widzialna natura jest bogatą w treści księga, mówiącą o życiu ziemskim i o życiu pozagrobowym. Trzeba tylko umieć z niej korzystać [...]"15.

Myśl chrześcijańskiego Wschodu - pisze Clément - przedstawia z jednej strony rzeczywistość własną wszechświata stworzonego, a z drugiej - jego przejrzystość (transparence possible), która pozwala mu, przez człowieka uczestniczyć w "energiach" Bożych" ${ }^{16}$.

W chrześcijaństwie świat nie jest "sierotą"; nie jest również zwykłą emanacją Boskości - Absolutu. Wychodzi on nowy z rąk Boga żywego, jest chciany przez Boga, „radujący się tą radością adoracyjną, która jest opisana w Psalmach i w Księdze Hioba, a w której konstelacje wykrzykują w "hymnie cudownie skomponowanym" "17. Stworzenie - stałe przechodzenie od nicości do bytu, w ożywieniu nieskończoności, jest tym poruszeniem, w którym są ofiarowane: czas, przestrzeń, struktura materii: „Ten świat jest "pól - bytem” (semi - être) ciągle płynącym, wibrującym, poza którym "duchowe ucho" dostrzega inną rzeczywistość ${ }^{18}$.

Cyt. za: O. CLÉMENT, Alle fonti con i Padri..., s. 210.

1 Tamże, s. 210.

12 T. ŠPIDLIK, Myśl rosyjska. Inna wizja czlowieka, Warszawa 2000, s. 243.

13 O. CLÉMENT, Alle fonti con i Padri..., s. 211.

14 T. ŠPIDLIK, Myśl rosyjska. Inna wizja cztowieka, s. 243.

15 Prokofij KOROPCEW, Publicznyje cztienija.... Woroneż 1878, s. 65.

16 O. CLÉMENT, L'oeil de feu. Deux visions spirituelles du cosmos, Paris 1994, s. 71.

17 O. CLÉMENT, Questions sur l' homme, Paris 1972, s. 147. Zob. też: L'oeil de feu..., s. 71.

18 P. FłORENSKI cyt. w: O. CLÉMENT, Questions sur l'homme, s. 147. 


\section{1. Rzeczywistość własna wszechświata stworzonego}

Świat i wszechświat - według Clément - nie jest ani zwykłą „emanacja", ani zwykłym uporządkowaniem wcześniej istniejącej materii przez nieokreślonego bliżej demiurga. Świat został stworzony z niczego (ex nihilo). To ostatnie słowo jest pojęciem - limitem, ograniczającym (un concept - limite); daje ono do zrozumienia, że Bóg, w którym nie ma nic, ani nikogo "poza" (en dehors), pozwala na istnienie rzeczywistości "różnej” (autre) od Niego poprzez pewnego rodzaju "cofnięcie się", ofiarne uniżenie, co chrześcijanie nazywają kenosis, a mistyka hebrajska tsimtsum ${ }^{19}$. Stworzenie jest dziełem woli Boga, woli wolnej i miłującej. Ojcowie greccy nadają platońskiemu pojęciu "boskich idei", charakter dynamiczny, intencjonalny, odwołując się do biblijnego pojęcia „Stowa" ${ }^{20}$. Wszechświat nie jest kopią ani wyblakłym odbiciem świata Boskiego, rodzi się on jako coś nowego, "wewnątrz" i "przez" stwórcze Słowo Boga. Ojcowie Kościoła nazywają stworzenie "harmonią muzyczną", albo "boskim hymnem cudownie skomponowanym"21. Hymn, muzyka, ruch rytmiczny i stawanie się stworzeń rodzi się z komunikowania ciagle nowego; „,informacji" pochodzacych od Transcendencji. Stworzenie przechodzi $w$ ten sposób „od nicości do istnienia w przyciąganiu nieskończoności"22.

W ten sposób natura, w widzeniu chrześcijańskim, jest rzeczywistością nową, prawdziwą, dynamiczną, ożywioną przez świetlaną siłę Boga, którą On umieszcza w stworzeniu jako orientującą w kierunku Transcendencji. Tylko tradycja judeo-chrześcijańska pozwoliła na właściwą interpretację sensu stworzenia. Dlatego wszelkie dociekania naukowe, dotyczące natury, powinny zakładać objawienie biblijne ${ }^{23}$. Tylko wtedy: „ludzie nie będą widzieć $\mathrm{w}$ stworzeniu siedziby demona, ale pewien rodzaj rozprzestrzeniania się, mirażu Boskości, na podobieństwo tęczy w kropli wody; tylko wtedy możliwe będzie pojęcie świata jako stworzenia Bożego, autonomicznego $\mathrm{w}$ swoim istnieniu, $\mathrm{w}$ swoim usprawiedliwieniu $\mathrm{i} w$ swojej odpowiedzialności"24.

Chwała Boża, „łaska niestworzona”, Jego „energia” objawia się u samych podstaw wszystkich rzeczy. W swojej prawdziwej istocie, pisze $\mathrm{O}$. Clément, całe stworzenie, a szczególnie czlowiek "ma korzenie niebieskie" (a des racines célestes) ${ }^{25}$. W jego "logosie", w jego „imieniu", żywym

19 O. CLÉMENT, L'oeil de feu..., s. 71-72.

20 Jest to np. ,myśl - wola”, theletike ennoia, o której pisze św. Jan Damasceński w: De fide orthodoxa, 11,2. Tamże, s. 72.

21 GRZEGORZ Z NYSSY, In Psalmorum inscriptiones I, 3; th. whoskie: Sui titoli dei salmi, a cura di A. Traverso, Roma 1994, s. 44.

22 O. CLÉMENT, L'oeil de feu..., s. 72.

23 O. CLÉMENT, Questions sur l'homme, s. 148.

24 Tamże, s. 148.

25 Tamże, s. 148. 
słowie, dzięki któremu Bóg je pobudza do istnienia, stworzenie na swój sposób wyraża chwałę Bożą poprzez samo swoje istnienie, ponieważ: „Inny jest blask słońca, a inny - księżyca i gwiazd. Jedna gwiazda różni się jasnością od drugiej" (1 Kor 15,41). Każde stworzenie oddaje chwałę Bogu na swój jedyny, niepowtarzalny sposób ${ }^{26}$.

Świat jednak nie jest Bogiem, ale jest Jego świątynią, Jego "miejscem” (un lieu), miejscem Jego "serca”. Im bardziej natura jest pełna, żywa, bogata $w$ soki, tym szersze jest jej symboliczne znaczenie. Symbol nie nakłada się na rzeczy, ale jest samym ich bogactwem, dynamizmem natury rzeczy powołanych do dopełniania się $\mathrm{w} \mathrm{Bogu}^{27}$. W ten sposób zostaje zanegowany zarówno wszelkiego rodzaju substancjalizm pochodzenia arystotelesowskiego, jak i wszelkiego rodzaju subiektywizm wiary. "Idee” Boże determinują sposób, według którego byty partycypują w Bożych „energiach”. Pisze Clément: „Każdy byt, każda rzecz, każdy związek pomiędzy bytami i rzeczami jest wzbudzany i niesiony przez stowo żywe, przez logos. Bez tego logosu, bez imienia, w bycie stworzonym nie byłoby niczego innego oprócz absurdalnego zderzenia się głuchych i niemych mas, w otchłani ciemności"28. Wszystkie te logoi są wyrażeniem Logosa, albo Mądrości Bożej.

Clément wyjaśnia, że Bóg przemawia do człowieka światem. Bóg i czlowiek rozmawiaja ze sobą przy pomocy świata. Logos Boży nadaje światu strukturę, a Jego Tchnienie świat ożywia i sprawia, że ten dąży do harmonii i piękna. Logos i Tchnienie, to "dwie ręce Ojca", który jest - ródłem każdej rzeczywistości ${ }^{29}$.

Należy dodać, że tylko to, co duchowe i rozumne (w sensie rozumności Bożej i anielskiej) umożliwia ukazanie się tego, co widzialne. Biblia, mówiąc o stworzeniu człowieka, określa go jako "ciało ożywione" albo "duszę żyjącą". Dla Grzegorza z Nyssy to, co umożliwia pojawienie się rzeczy widzialnych jest syndrome, ${ }^{30}$ spotkaniem i konkretyzacją wartości rozumnych, to co dla teologa D. Staniloaë jest ich „plastyfikacja”" ${ }^{\prime 2}$. To, co widzialne jest manifestacją tego, co niewidzialne, jest jego symbolem. Podmiotem tych "myśli", tych "pojmowań, rozumowan", jest z jednej strony Logos Boży, a z drugiej - człowiek loghikôs, powołany do wyrażenia wszystkich logoi, tzn. "duchowego znaczenia" wszystkich rzeczy ${ }^{32}$.

Tamże, s. 148

Tamze, s. 148-149.

28 O. CLÉMENT, Les visionnaires, Paris 1986. Wyd. włoskie: I visionari. Saggio sul superamento del nichilismo, Milano 1987, s. 157 - 158.

29 IRENEUSZ Z LIONU, Przecin' herezjom. IV, 20, 1.

3.) Grzegorz z Nyssy, De anima et resurectione, PG 46, 124c.

31 Zob. O. CLÉMENT, I visionari..., s. 159.

2 Tamże, s. 159. 
Ojcowie Kościoła podkreślają, iż Mądrość i Potęga Boża, o których pisze św. Pawel, a które odnoszą się do świata, to Syn Boży i Duch Święty. Odczytanie wszechświata jest możliwe tylko w świetle Trójcy Przenajświętszej, ponieważ Sens wszechświata objawia się w Logosie, a Duch jest Podmuchem - Tchnieniem ożywiającym, prowadzącym do Sensu każdą rzecz i cały wszechświat. Świat jest dla chrześcijanina tekstem trynitarnym, jest symbolem Logosa, wątkiem, symbolem, dynamizmem Ducha - Pneuma ${ }^{33}$.

Cały kosmos został tajemniczo umocniony i zbawiony przez krzyż Chrystusa. Przez Chrystusa został pociągnięty „do zjednoczenia bez pomieszania” z Bogiem. Pierwsi chrześcijanie, nie śmiejąc przedstawiać bezpośrednio krzyża, jako znaku przerażenia i hańby, widzieli go we wszystkich rzeczach: w locie ptaków, w rozgałęzieniu drzew, w statku z żaglem ${ }^{34}$. Dzisiaj odkrywamy, że krzyż jest wpisany w sam skład materii, na co wskazuje współczesna fizyka, nie mogąca studiować swojego przedmiotu bez mnożenia antynomii. Rytm śmierci - zmartwychwstania jest udziałem całego kosmicznego "stawania się". Zmienia on przerażenie w pewien rodzaj ofiary i znajduje swoje dopełnienie $w$ transformacji Wielkanocy, która przyjmuje $w$ sobie całe życie razem $z$ całym cierpieniem świata stworzonego ${ }^{35}$. Ta wizja "Ofiary Miłości" powinna przenikać patrzenie człowieka na byty i rzeczy: "Widzisz słońce, pomyśl o Tym, który jest Światłością świata, często zakrywaną przez ciemności. Widzisz drzewa i ich zielone gałęzie, pomyśl o Tym, który, wisząc na drzewie, wszystko przyciąga do siebie. Widzisz kamienie, skały, pomyśl o kamieniu, który w pewnym ogrodzie zamykał wejście do grobu. Został odsunięty i od tamtej pory wejście do tego grobu nie zostało nigdy zamknięte" ${ }^{\prime 36}$.

Człowiek kontemplujący - według Clément - na równi z nie czytającym, już nie potrzebuje książek. Byty i rzeczy w ich ogromnej subtelności i delikatności mówią mu ciągle o Bogu. Słowa św. Pawła: „Wszystko jest wasze, wy Chrystusa, a Chrystus Boga" (1 Kor 3, 27) można by odwrócić: „Bóg jest Chrystusa, Chrystus jest wasz, a wy wszystkich rzeczy" ${ }^{37}$.

Świat jest darem od Boga dla człowieka. Człowiek powinien umieć odgadnąć, dostrzec Dawcę za pomocą daru: "Po Wcieleniu, Śmierci i Zmartwychwstaniu, ziemia stała się jedną wielką relikwią, grobem, macierzą, w której Chrystus był pochowany, i której, zmartwychwstając, ofiarował nowe życie. Drzewo krzyża natomiast, stawszy się drzewem życia, utożsamia tajemniczo ziemię $\mathrm{z}$ rajem, uwydatniając tym samym sakramentalność wszystkich rzeczy"38.

3 O. CLÉMENT, Alle fonti con i Padri.., s. 210.

Tamże, s. 210.

Tamże, s. 210-211.

36 Slowa pewnego mnicha Wschodu w: Amour sans limite, Chevetogne 1971, s. 27-28.

37 O. CLÉMENT, Alle fonti con i Padri.., s. 211.

38 Tamże, s. 211. 


\section{2. Partycypacja kosmosu w ,energiach” Bożych}

Pisaliśmy wyżej, że tylko to, co duchowe, to, co rozumne, w sensie rozumności Boskiej i anielskiej, pozwala na ukazanie się tego, co widzialne. W Objawieniu biblijnym pojęcie "ciała” występuje zawsze jako "ciało ożywione" i „dusza żyjąca". "Ciałem ożywionym" i "duszą żyjącą" jest czlowiek, który, będąc istotą duchowo - cielesną, skupia w sobie to, co niematerialne $\mathrm{i}$ to, co materialne. Będąc obrazem Boga, jest naznaczony boskością i uczestniczy w Boskim intelekcie. Cały wszechświat stworzony może uczestniczyć w "energiach" Bożych tylko przez człowieka ${ }^{39}$. Człowiek, uczestniczący w liturgii Kościoła, umożliwia to uczestnictwo całemu wszechświatu. W celebracji, w której Duch Święty aktualizuje, manifestuje Śmierć i Zmartwychwstanie Chrystusa, "ciało śmiertelne” cały wszechświat stworzony, zakryty przez matowość człowieka, powoli napełnia się wiecznością i rozpoczyna swoją metamorfozę $w$,ciało chwalebne ${ }^{\prime 40}$. Kościół jako "misterium życia” jest w centrum rozchodzenia się, promieniowania egzystencji kosmicznej: „Sama materia [...] otrzymuje w sobie siłę Boga"41. Pod prześwitującym welonem sakramentu upadła modalność natury zostaje wchłonięta przez modalność chwalebną. "Energie” Boże przenikają materię sakramentów zarówno w postaci wody chrzcielnej jak i oleju namaszczenia ${ }^{42}$.

W Kościele Wschodnim gałązki i kwiaty są poświęcane w dzień Pięćdziesiątnicy, owoce $w$ dzień Przemienienia, ziarno, olej, chleb i wino podczas każdej wigilii. Wszystko zaś kulminuje w métabolè eucharystycznej, podczas której chleb i wino, w pojęciu chrześcijańskiego Wschodu sa "przemienione", a to, znaczy, co innego niż "przeistoczone" ${ }^{43}$. Człowiek ofiaruje Bogu całą przyrodę, cały świat stworzony, aby stawał się Eucharystią ${ }^{44}$. W anaforze „człowiek liturgiczny" wspomina niebo i ziemię, morze i słońce, księżyc i gwiazdy, całe stworzenie rozumne i nierozumne, widzialne i niewidzialne ${ }^{45}$.

39 Zob. O. CLÉMENT, L'oeil de feu..., s. 71.

40 Tamże, s. 71.

41. GRZEGORZ Z NYSSY, In baptismum Christi, PG 46, 581B.

42 O. CLÉMENT, L'oeil de feu ..., s. 72.

43. „Et tout culmine à la métabolè eucharistique où le pain et le vin, dans la conception de l'Orient chrétien, sont moins «transsubstantiés» que transfigurés". O. CLÉMENT, L'oeil de feu..., s. 89. Teologia wschodnia w interpretacji Eucharystii zatrzymała się na słowie greckim „metabole”, teologia zachodnia od XII w. posługuje się lacińskim terminem „transsubstantiatio". O. Clément odnosi się z niechęcią do tego terminu.

44 Zob. m.in. P. Teilhard de Chardin, La Messe sur le Monde, Paris 1965.

45 Myśl Cyryla Jerozolimskiego w: O. CLÉMENT, L'oeil de feu..., s. 89. 
Liturgia armeńska głosi: „Niebo i ziemia są pełne Twojej chwały dzięki epifanii naszego Pana, Boga i Zbawiciela Jezusa Chrystusa, [...] ponieważ przez Mękę Twojego Syna, wszystkie stworzenia zostały odnowione"46. Jest to "diafania" Chrystusa chwalebnego, Chrystusa kosmicznego, który odpowiada i wychodzi naprzeciw oczekiwaniom całego stworzenia.

Człowiek, przez którego i dzięki któremu, całe stworzenie otwiera się na „energie" Boże oraz odnawia się przez to otwarcie, powinien uczynić (jak w Kościele) "nawę” ze swego ciała, a ze swej duszy "sanktuarium" - święte świętych, w którym będzie mógł ofiarować Bogu logoi znaczenie, sens całego wszechświata ${ }^{47}$. W Kościele człowiek doświadcza "egzystencji eucharystycznej”, staje się człowiekiem liturgicznym, ofiarowującym Bogu całe stworzenie. Tam właśnie odkrywa sakramentalność istnienia własnego i całego kosmosu. Kosmos został już tajemnie przemieniony w Chrystusie, ale człowiek powinien współpracować z Bogiem, w dalszej jego przemianie. Eucharystyczna świadomość człowieka - zgodnie $z$ tym, co pisze św. Paweł: „W każdym położeniu dziękujcie [...]” (1 Kor 5, 18) - poszukuje w samym sercu wszystkich bytów i rzeczy, punktu przejrzystości, przez który mogłoby promieniować Światło - energie Chrystusa kosmicznego ${ }^{48}$.

Wzywanie Imienia Jezus, popularne w mistyce Wschodu chrześcijańskiego, wciąga wszystko, co istnieje, w to ofiarne poruszenie: „Możemy stosować to Imię do osób, do książek, do kwiatów, do wszystkiego, co spotykamy, widzimy, o czym myślimy. Imię Jezusa może stać się kluczem mistycznym, który otworzy świat, narzędziem tajemniczej ofiary każdej rzeczy i każdej osoby, przyłożeniem Boskiej pieczęci do świata [...] jest to metoda przeobrażania świata" ${ }^{\prime 9}$.

\section{Człowiek kapłanem i stróżem wszechświata}

Świat "stoi naprzeciw” czlowieka jako pierwsze objawienie Boga. Do człowieka należy odczytanie tego objawienia i - jak pisze O. Clément "uświadomienie sobie ontologicznego uwielbienia wszystkich rzeczy" W związku tajemniczo oblubieńczym między człowiekiem a wszechświatem, wszechświat jest jak bezosobowa kobiecość, która "stoi naprzeciw” i jednocześnie tworzy z człowiekiem jedno ciało. Cały wszechświat wi-

\footnotetext{
4h Tamże, s. 89-90.

47 Tamże, s. 90.

48 Tamże, s. 90.

49 Mnich Kościoła Wschodniego, La preghiera di Gesù, a cura delle benedettine del Monastero di Santa Scolastica, Brescia 1964, s. 98-99.

5) O. CLÉMENT. Questions sur l'homme, s. 149.
} 
dzialny jest przedłużeniem ciała człowieka, ciało człowieka nie jest niczym innym, jak strukturą, jaką jego osoba, jego "dusza żyjąca”, nadaje "uniwersalnemu prochowi wszechświata”51. Nie ma żadnej przerwy, luki pomiędzy ciałem świata a ciałem człowieka; świat jest jednocześnie cialem ludzkości.

Człowiek jest „małym światem” (mikrokosmosem), który skupia, kondensuje, rekapituluje wszystkie poziomy bytów stworzonych i może $w$ ten sposób poznawać wszechświat od wewnątrz. Pierwszy opis stworzenia ( $\mathrm{Rdz} 1,26$ - 31) ukazuje człowieka - mikrokosmos, stworzonego po innych bytach; choć upodobnionego do nich jednym błogosławieństwem, to jednak będącego szczytem stworzenia, jego ukoronowaniem. Człowiek jednak, jest kimś o wiele więcej niż mikrokosmosem, jest osobą „na obraz Boga". W swojej wolności osobowej i odpowiedzialności człowiek transcenduje wszechświat, nie po to, aby go opuścić, ale po to, „aby go zawierać, nadawać mu sens, komunikować mu laskę ${ }^{\prime 52}$. W tym sensie człowiek jest kapłanem wszechświata. Wszechświat poprzez człowieka jest przeznaczony do stawania się „obrazem obrazu"53. W tym sensie należy interpretować drugi opis stworzenia ( $\operatorname{Rdz} 2,4 b-25)$, który umieszcza człowieka "na początku" wszechświata stworzonego. Tylko człowiek jest ożywiony przez tchnienie Boga i bez niego "rośliny" nie mogłyby rosnąć, tak jakby w człowieku one "zapuszczały swoje korzenie" ${ }^{\text {"54. To on }}$ „nadaje imiona" zwierzętom, odkrywając również ich duchowe znaczenie. Tylko człowiek, zarówno król, jak i kapłan stworzenia, może pozwolić kosmosowi odpowiedzieć na jego tajemniczą sakramentalność. Człowiek został umieszczony w ogrodzie, aby "go uprawiał", aby pomnażal jego piękno.

Niektórzy teologowie prawosławni piszą, że ludzkość powinna stać się Mesjaszem kosmicznym, zbiorowym, przeznaczonym do tego, aby "czynić sobie ziemię poddaną", tzn., "aby ją przemieniać i upiększać"55. Człowiek, jako kapłan i stróż stanowi dla wszechświata nadzieję otrzymania łaski i zjednoczenia $z$ Bogiem, ale może też stać się ryzykiem upadku i degeneracji wszelkiego ciała, bo oddalony od Boga będzie widział rzeczy tylko powierzchownie i nada im fałszywe "imię". W stwierdzeniu tym odzywa się Pawłowe: „Bo stworzenie z upragnieniem oczekuje objawienia się synów Bożych. Stworzenie, bowiem zostało poddane marności - nie z własnej chęci, ale ze względu na Tego, który je poddal - $w$ nadziei, że również i ono zostanie wyzwolone $\mathrm{z}$ niewoli zepsucia, by

\footnotetext{
51 Tamże, s. 149.

52 Tamże, s. 150 .

53 Określenie Grzegorza z Nyssy, w: O. CLÉMENT, Questions sur l'homme, s. 150.

54 Tamże, s. 150.

55 Tamże, s. 150.
} 
uczestniczyć w wolności i chwale dzieci Bożych. Wiemy przecież, że całe stworzenie aż dotąd jęczy i wzdycha w bólach rodzenia ( $R z$ 8, 19 - 21).

W ten sposób i w tym znaczeniu wszystko, cokolwiek dzieje się w człowieku, ma znaczenie uniwersalne i pozostawia ślad we wszechświecie. Przeznaczenie człowieka określa przeznaczenie kosmosu. Objawienie biblijne, w swoim symbolicznym znaczeniu, stawia człowieka wobec zdecydowanego antropocentryzmu, nie fizycznego, ale duchowego. Człowiek będąc jednocześnie "mikrokosmosem" i "mikrotheosem”, syntezą wszechświata i obrazem Boga, jest „osią duchową" wszystkich bytów stworzonych, wszystkich ich zamierzeń, a Bóg, aby zjednoczyć się na nowo ze wszechświatem, stał się człowiekiem ${ }^{56}$.

Przejście, we współczesnej nauce, od geocentryzmu do heliocentry$z m u$, tzn. do absencji jakiegokolwiek centrum w „niezdefiniowanej bliżej fizyczności”, nie może poddawać dyskusji tego "osiowego” znaczenia człowieka we wszechświecie, lecz nadaje mu znaczenie odnowione. Niezdefiniowany kosmos nie daje się zdefiniować i usytuować poza stwórczą miłością Boga, w której człowiek może świadomie uczestniczyć. Dla ludzi, którzy odrzucają, albo ignorują Żyjącego, nie istnieje już ani wysokość, ani niskość, tylko chłód i ciemność. Dla tych jednak, którzy wiedzą i wierzą, serce człowieka, szczególnie świętego, jest „miejscem Boga", a tym samym swoistym centrum wszechświata; to serce nawet zawiera wszechświat, jako przejaw stwórczej miłości Boga ${ }^{57}$.

Sytuacja kosmosu, jego przejrzystość, albo matowość (nieprzejrzystość) na Boże światło zależy od przejrzystości albo matowości człowieka - kapłana kosmosu. Człowiek, bowiem, podporządkowując siebie "pustce", podporządkował cały wszechświat pewnemu stanowi "przeciw naturze" całej materii ${ }^{58}$.

\section{1. Czlowiek - logikôs}

Człowiek - logikôs jest duchowym centrum wszechświata. Jako mikrokosmos skupia go w sobie, a jako obraz Boży transcenduje go, zawiera i nadaje mu znaczenie ${ }^{59}$. Człowiek jest potencjalnie „hipostazą", „osobą”, nie w znaczeniu psychologicznym lub socjologicznym, które nie wychodzi poza poziom indywidualny, ale $w$ znaczeniu trynitarnym, $w$ sensie jedynego sposobu istnienia, bez możliwości konfrontacji. Pisze M. Berdiajev: „Osoba jest jedyną potencją, w jedynej formie całego wszechświa-

56 Tamże, s. 151

57 Tamże, s. 151-152.

58 Tamże, s. 153.

59 Zob. m.in. O. CIÉMENT, I visionari..., s. 159-160; L'oeil de feu ..., s. 74. 
ta"60. Człowiek jest, więc powołany do tego, aby stać się „hipostazą" całego kosmosu, aby go wyrazić, nadać sens temu logos àlogos. W człowieku aktualizuje się, "według Bożej mądrości, fuzja i zmieszanie tego, co widzialne, z tym, co rozumowe", zespolenie boskości z ziemskością, dzięki czemu przez niego "może rozprzestrzeniać się łaska na całe stworzenie $^{\prime 61}$. Wszechświat objawia się przez człowieka jako „obraz obrazu”, według myśli Grzegorza z Nyssy.

Człowiek - logikôs jest królem - kapłanem, który zbiera logoi - znaczenie wszystkich rzeczy, aby ofiarować je Logosowi - najwyższemu Sensowi rzeczy i umożliwić tym samym rozprzestrzenianie się chwały od istnień nieskończenie małych do nieskończenie wielkich, które zgłębia „rozum człowieka"62.

Oczywiście, dla ludzi, którzy nie mają nic wspólnego z doświadczeniem duchowym, świat i wszechświat jest - twierdzi Clément - tylko „nieskończonym więzieniem”, w którym wszystko jest samotnością, zimnem i ciemnością, ale dla tych, którzy poznają logoi - znaczenie wszystkich rzeczy, świat jest mieszkaniem Boga. O świecie należy jednak powiedzieć, że jest "nie definiowalny", ale nie jest "nieskończony" (qu'il est indéfini mais non infini), pisze $\mathrm{O}$. Clément $\mathrm{t}^{63}$.

Mistyczna kosmologia Wschodu chrześcijańskiego jest nierozdzielnie związana z czasowością i doczesnością. Z doczesnością nieodwracalną, ponieważ wchodzi ona do dramatu interpersonalnego, ale jednocześnie odwracalną, ponieważ wcześniejsze Wizyty ${ }^{64}$ a potem Wcielenie Słowa Bożego otwierają i rekapitulują ją, łączą z wiecznością, umożliwiając liturgiczną cyrkulację między "alfą" i „omegą". Jest to „omega” - koniec, dopełnienie w Bogu "wszystkiego we wszystkim”, która zamyka rajską "alfę", ale sprawia, że następuje na nowo raj ${ }^{65}$.

Stworzenie piękna i dobra (tob lub tow po hebrajsku) krzyżuje się nieustannie z upadkiem, który poprzez wolność człowieka - logikôs i aniołów, nadaje nicości paradoksalną konsystencję i możliwość rozcięcia i rozpadu bytów stworzonych ${ }^{66}$. Jeżeli nawet stworzenie "dobre i piękne" jest utkane $\mathrm{z}$ nicości i owinięte złudzeniem, jeżeli nawet piękno staje się dwuznaczne, to i tak pozostaje faktem, że Mądrość Boża pozwala wszystkim

\footnotetext{
60 N. BERDIAEV, De l'esclavage et de la liberté de l'homme, Paris 1963, s. 21 (wyd. rosyjskie: Paris 1939)

61 GRZEGORZ Z NYSSY, Oratio catechetica magna, 6; korzystamy z tłumaczenia włoskiego: Tenże, La grande catechesi, a cura di M. Naldini, Roma 1982, s. 61.

62 O. CLÉMENT, L'oeil de feu..., s. 74; zob. też: I visionari ..., s. 159.

63 O. CLÉMENT, L'oeil de feu..., s. 74.

64 Temat „wizyt Słowa” jest często poruszany przez apologetów II i III w., szczególnie przez \$w. Justyna, w odniesieniu do tradycji religijnych pozabiblijnych.

65 O. CLÉMENT, I visionari..., s. 160.

66. Tamze, s. 160
} 
logoi sprawiać, że rodzi się na nowo życie ze śmierci, że z podziałów powstają organizmy bardziej złożone ${ }^{67}$. Człowiek świadomie (logikôs), świadomy „obraz Boga" odkrywa wszędzie znaczenie rzeczy; w rzeczach odnajduje Mądrość Bożą: "To wszystko, co nazywamy rzeczywistością stworzoną - naturą, jest rzeczywistością symboliczną, odbiciem światła świata duchowego" ${ }^{\prime 68}$.

\section{2. Upadek czlowieka - katastrofą kosmiczną}

Wschodni Ojcowie Kościoła, zgłębiając wypowiedzi Biblii, wskazywali na upadek człowieka - grzech pierworodny, jako na prawdziwą katastrofę kosmiczną, zaciemnienie modalności rajskiej i pojawienie się nowego sposobu istnienia uniwersalnego. Człowiek - syn Boga postanowił "zabić" Boskiego Ojca, aby zawładnąć matką - Ziemią9. Św. Maksym Wyznawca pisał: „Człowiek zechciał zawładnąć rzeczami boskimi bez Boga i przed Bogiem, a nie według $\mathrm{Boga}^{70}$.

Człowiek przestał rozumieć prawdziwy świat, taki, jakim Bóg go stworzył i utrzymuje w swojej chwale. Stworzenie, podobnie jak Stwórca, nie narzuca się człowiekowi, który widzi wszechświat przez pryzmat swego własnego upadku, według własnej zachłanności i w ten sposób go zaciemnia, zasłania i czyni zatwardziałym. Powstają wskutek tego zbrodnicze modalności czasu, miejsca i materii; czas zbrodni, przestrzeń, która oddziela i więzi; materia, która staje się matowa, ograniczająca, lustro "duchowej śmierci człowieka"71.

Pomimo wszystko, Bóg, choć wyłączony z serca człowieka i z serca całego kosmosu, podtrzymuje człowieka i wszechświat od zewnątrz, wprowadzając pewien porządek, aby zapobiec totalnej dezintegracji, aby mogła realizować się historia zbawienia. Prawa natury, poprzez ciąglość, którą zapewniają, świadczą o kosmicznym przymierzu, jakie Bóg zawarł z ludzkością po potopie; również po potopie z wód "ludzkiej złości”, w których człowiek ryzykował swoje własne "roztopienie"72. Bóg, mimo złego usposobienia czlowieka (por. $\operatorname{Rdz} 8,21 \mathrm{a}$ ), zachowuje porządek i dotrzymuje obietnicy: „Przeto już nigdy nie zgładzę wszystkiego, co żyje, jak to uczyniłem. Będą, zatem istniały, jak długo trwać będzie ziemia: siew i żniwo, mróz i upał, lato i zima, dzień i noc" ( $\operatorname{Rdz} 8,21$ b - 22). Jednakże to przymierze, zawarte zarówno $z$ człowiekiem, jak i ze wszystki-

67 Tamże, s. 161.

68

Tamże, s. 165.

O. CLÉMENT, Questions sur l'homme, s. 153.

70 Cyt. Tamże, s. 153.

71 Tamze, s. 153-154.

72 Tamże, s. 154. 
mi „istotami żywymi”, zamyka w sobie różne formy śmierci, bo jest to tylko związek zewnętrzny między Bogiem a Jego stworzeniem. Istnieje nadal przemoc między człowiekiem a wszechświatem: „Zadanie człowieka będzie zawsze przypominane, ale wszechświat będzie się go bał, bo człowiek będzie zabijał po to, aby jeść, skoro został wykluczony $\mathrm{z}$ raju ${ }^{73}$. Całe stworzenie jęczy i wzdycha, oczekując wyzwolenia, bo zostało pozostawione siłom zła; tym siłom, które przejrzystość stworzenia zamienily na "mur".

W tej perspektywie, myśl chrześcijańska powinna brać pod uwagę problem ewolucji, świadoma tego, że odkrycia geologii i paleontologii zatrzymują się „przed drzwiami rajskimi”, ponieważ raj stanowi inny sposób istnienia. Nauka $w$ swych poszukiwaniach nie może sięgnąc do momentu przed upadkiem, ponieważ sama jest zamknięta $w$ uwarunkowaniach egzystencji, spowodowanych samym upadkiem. To, co nauka nazywa „ewolucja”, reprezentuje duchowo proces obiektywizacji, uzewnętrznienia egzystencji kosmicznej opuszczonej przez pierwszego Adama. Kosmos przestaje być ",iałem mistycznym" Adama i popada w separację i śmierć, gdzie Bóg jednak go ustanawia, chroni go i orientuje $\mathrm{w}$ kierunku Chrystusa - nowego Adama ${ }^{74}$.

\section{Wszechświat przemieniony w Chrystusie przez człowieka}

Teologowie Wschodu chrześcijańskiego, wśród nich O. Clément uczą że człowiek nie posiada żadnej mocy i władzy sam z siebie. Panem i Królem jest tylko Bóg, a czlowiek otrzymał od Boga zadanie "czynienia sobie ziemi poddaną" (Rdz 1, 28) i działa tylko w imieniu Boga. Człowiek może przemieniać świat, udoskonalając go, tylko na tyle, na ile będzie to czynił w łączności z Bogiem - Stwórcą. Każde samodzielne działanie człowieka, nie liczące się z Bogiem, prowadzi samego człowieka i cały kosmos do upadku a w rezultacie do utraty sensu - znaczenia, do prawdziwej śmierci, katastrofy kosmicznej.

Człowiekiem - Maximum, człowiekiem doskonałym jest Jezus Chrystus - nowy Adam. Jest On egzystencją osobową pełną - Synem Bożym. Kiedy przez Wcielenie staje się Synem ziemi, nie pozwala ogarnąć się wszechświatu, z jego czasem i przestrzenią, lecz w rzeczywistości On sam zawiera $w$ sobie wszechświat. Nie chce, poprzez swoje ciało, przywłaszczyć sobie świata, tak jak zdobyczy, ale poprzez postawę stale eucharystyczną, czyni go "ciałem jedności”, ciałem jednocześnie kosmicznym i eucharystycznym. W Nim kosmos staje się "cielesnością duchową", co nie

\footnotetext{
Tamże, s. 154.

74 Tamże, s. 155.
} 
oznacza - pozbawioną materii, ale ożywioną przez Ducha ${ }^{75}$. Chrystus dobrowolnie zamyka swoją świetlaną cielesność w cielesności ludzkiej, często cierpiącej, ociężałej i umęczonej, aby na krzyżu, a potem w poranek paschalny wszystko zostało oświecone, zarówno wszechświat, jak i każdy wysiłek człowieka zmierzający do przemiany wszechświata. Chrystus jest Tym, który przemienia; czyni to we współpracy z człowiekiem. Potrzebuje wolnej odpowiedzi i zaangażowania oraz pracy człowieka, aby ta przemiana mogła się realizować już tu $\mathrm{w}$ historii. Ciało i krew Chrystusa w Eucharystii to nie tylko pszenica i winogrona, ale także chleb i wino - owoce pracy i wysiłku człowieka. W Chrystusie, przez człowieka, materia nie narzuca już swoich determinizmów, lecz staje się na nowo środkiem komunii, czasem i radością spotkania. Świat, "zamrożony" przez upadek człowieka, rozgrzewa się w ogniu Ducha, odnajdując na nowo swój pierwotny dynamizm. Czas i przestrzeń nie stanowią już podziału, ale przechodzą do wymiaru zmartwychwstania ${ }^{76}$.

Zmartwychwstanie Chrystusa i Jego wyniesienie do chwały mają znaczenie kosmiczne. Krzyż staje się drzewem życia i pozwala ludziom uczestniczyć w zmartwychwstałej modalności bytów stworzonych. Wszystkie rzeczy niosą $w$ sobie rzeczywistość krzyża, zapowiadającego ich zmartwychwstanie. Świat, chociaż już przemieniony i oświecony przez Chrystusa, pozostaje nadal w swojej matowości, będącej konsekwencją matowości człowieka. Definitywne wyzwolenie i przemienienie wszechświata wymaga nie tylko tego, aby Bóg stał się człowiekiem, ale również tego, aby człowiek stawał się Bogiem - otwierał się w całej swej egzystencji na Boga. Chrystus uczynił ludzi zdolnymi do przyjęcia Ducha, tzn. do współpracy przy realizacji Królestwa ${ }^{77}$ : Człłowiek uświęcony, przemieniony w Chrystusie, to człowiek, który sam uświęca i przemienia"78.

\section{Człowiek i technika}

Spośród wielu przejawów ludzkiej aktywności, technika, szczególnie w ostatnim stuleciu, dokonała największego postępu. Spotkać ją można wszędzie: w polityce, gospodarce, nauce, sztuce, rzemiośle i innych najbardziej drobnych działaniach człowieka. Trudno byłoby wyobrazić sobie dzisiaj życie człowieka bez osiągnięć techniki ${ }^{79}$. Rozwój ten jest sam

75 Tamże, s. 156.

76 Tamże, s. 156.

$\pi$ Tamże, s. 157.

78 Tamże, s. 159.

79 E. OZOROWSKI, Techmika w interpretacji filozoficzno - teologicznej, w: Cztowiek, etyka, ekonomia, pod red. R. Horodeńskiego i E. Ozorowskiego, Bialystok 2001, s. 75. 
w sobie pozytywny, ponieważ ujawnia moce ludzkiego umysłu. Człowiek może jednak używać techniki na dobre i na złe. Zależy to głównie od tego, w jakiej pozostaje do niej relacji i jak się nią posługuje $\mathrm{w}$ relacji $\mathrm{z}$ innymi ludźmi. $Z$ tego względu technika wymaga nieustannej refleksji ${ }^{80}$.

Pojęcie techniki dzisiaj wykracza znacznie poza obręb, który w starożytności wyznaczała grecka "techne". Wtedy określała ona umiejętność zrobienia czegoś lub pokierowania kimś. W języku lacińskim była to "ars", co do dziś tłumaczy się jako sztuka. Umiejętność ta polegała na znajomości reguł, rządzących światem rzeczy i osób. Działania irracjonalne uważano za przeciwieństwo sztuki.

W takim znaczeniu używa się słowa „technika” i we współczesnych językach europejskich (np. technika gry na fortepianie lub skoków narciarskich). To znaczenie pozostaje jednak w cieniu innego, tzn. techniki jako tworzonych przez człowieka środków materialnych oraz składających się na wiedzę techniczną reguł posługiwania się tymi środkami, jak też projektów stosowanych do zdobywania, przekształcania i wykorzystywania dóbr materialnych ${ }^{81}$.

Wprawdzie technika jest cząstką rzeczywistości świata, ale człowiek, który ją tworzy i adresat, który otrzymuje jej produkty, wychylony jest ku nieskończoności i wieczności. Dlatego, aby poznać technikę potrzebne jest użycie rozumu i wiary powiązanych ze sobą ${ }^{82}$.

\section{1. Technika w świetle Objawienia biblijnego}

Według przedstawicieli wschodniej myśli teologicznej w refleksji na temat techniki należy odwoływać się bezpośrednio do Objawienia biblijnego i podkreślać fakt, że człowiek $w$ momencie stworzenia otrzymał od Boga zadanie troszczyć się o ogród, "strzec go i uprawiać” (por. Rdz 2, 15). Rajski ogród oznacza wszechświat stworzony, w którym Bóg umieścił człowieka i powierzył mu go. „Uprawiać” ogród oznacza rozwijać jego możliwości. "Przeobrażenie” ogrodu - świata to dla wielu teologów prawosławnych, m.in. dla Sołowiowa, zadanie wyjściowe, które miało umożliwić rozwiązanie wszelkich problemów społecznych ${ }^{83}$. Z tego względu "kosmologia duchowa" powinna poprzedzać zagadnienie sprawiedliwości społecznej ${ }^{84}$. M. Berdiajew pisze: "Moje zbawienie i przemiana są związane nie tylko ze zbawieniem i przemianą innych ludzi, lecz także zwierząt, roślin i minerałów, z ich włączeniem do Królestwa Boże-

\footnotetext{
Tamże, s. 75 .

Tamże, s. 76.

JAN PAWEŁ II, Fides et ratio, nr 1.

83 Zob. m.in. T. ŠPIDLIK, Myśl rosyjska. Inna wizja człowieka, s. 251.

84 Tamże, s. 251.
} 
go, które zależy od moich wysiłków twórczych"85. Wszelka, zatem działalność człowieka, wszelki jego wysiłek, technika powinny mieć na uwadze nie tylko używanie dóbr tego świata w „drapieżnym utylitaryzmie", lecz również troskę o jego upiększanie i rozwój.

Zdaniem O. Clément, prawdziwe problemy techniki dzisiaj nie są wlaściwie techniczne, lecz duchowe. Trzeba postawić sobie pytanie: Jakiemu obrazowi człowieka i natury możemy przypisać obecną "drapieżną rewolucję techniczną" ${ }^{86}$. Technika, pozostawiona sama sobie, a jeszcze bardziej woli zysku oraz dominowania bogaczy i potężnych, stała się ślepa na prawdziwe potrzeby człowieka, na potrzebę chleba, dobra i piękna. Na Wschodzie i na Zachodzie, zabrakło w technice celu duchowego, który uczyniłby $z$ niej środek, narzędzie, a nie przeznaczenie. Może w tym pomóc jedynie biblijna prawda objawiona.

Biblia ukazuje dynamizm i tragedię ludzkiej wolności, gdy ona miast szukać Boga żyjącego, odrzuca Go. Czasem bywa tak, że człowiek podświadomie szuka Boga, poszukuje znaczenia wszystkiego, co istnieje. Zdaniem Clément, od czasu powołania Abrahama i od czasu krzyża Jezusa człowiek wyrusza na poszukiwanie, a rana - otwarcie na Nieskonczoność jest obecna zarówno w człowieku, jak i w całym świecie. Świat, choć w niejasności, oczekuje przeobrażenia go w królestwo Boże ${ }^{87}$. Nauka i technika współczesna powinny mieć coś z tego "otwarcia”, tego "nieograniczenia", zrodzonego z pewnego „wyruszenia” w kierunku nowej ziemi, tak jak Abraham. Poszukiwanie czegoś nowego jest w człowieku ciągle żywe. Człowiek wyrusza $\mathrm{z}$ domu, często nie wiedząc, dokąd i walczy z Bogiem, tak jakby On był deus ex machina ludzkiej ignorancji i bezsilności, a nie jako Ten, który umiera na krzyżu, aby dać wolność każdemu człowiekowi ${ }^{88}$.

To On - Chrystus pokazał prawdziwe znaczenie pracy człowieka. W Indiach $\mathrm{i}$ innych krajach Dalekiego Wschodu dominuje pogląd, że człowiek poprzez swój wysiłek może się „rozpłynąć” w kosmosie (cosmiser), chrześcijaństwo natomiast ukazuje naturę naznaczoną łaską Bożą, odnajduje w przyrodzie "prawie” oblicze, staje się ona "obrazem obrazu” tzn. człowieka - obrazu Boga. Połączenie prawdy objawionej ze starożytną mądrością "zgromadziło" energie, które pomogły rozwojowi techniki na Zachodzie ${ }^{89}$.

Clément twierdzi, że kiedy w średniowieczu zaczął panować racjonalizm i pojawił się wąsko pojęty humanizm, powstał rozłam pomiędzy

\footnotetext{
N. BERDIAEFF, De la destination de l'homme, Paris 1935, s. 377.

O. CLÉMENT, Questions sur l'homme, s. 162.

Tamże, s. 163.

Tamże, s. 163.

Tamże, s. 165.
} 
chrześcijaństwem a ludzkością w porządku stworzenia. Jego zdaniem jedynie w kulturze bizantyjskiej, a potem we franciszkańskiej Italii, pojawiły się elementy teologii przeobrażenia ciała i ziemi. Według tego myśliciela kultura zachodnia nie starała się zapłodnić „energiami” Bożymi rozwoju nauki i techniki. Kosmiczne "odrodzenie" zostało zaniechane przez Europę - przedreformacji i kontrreformacji. Chrześcijaństwo stało się tylko religią duszy i indywidualną moralnością, bez możliwości realnej metamorfozy w Boże człowieczeństwo. Rozwój owej racjonalności nie był, w większości przypadków, kierowany przez Ducha ${ }^{90}$.

Objawienie biblijne, powinno być dla twórców techniki, szczególnie chrześcijan, światłem w kierunku transfiguracji natury. Człowiek często nie zdaje sobie $z$ tego sprawy, że wszechświat techniczny, pozostawiony samemu sobie rani i zniekształca możliwości człowieka ${ }^{91}$. To człowiek, według Bożego zamiaru, ma kierować techniką, a nie technika człowiekiem, ponieważ z techniką wiąże się coś dobrego i złego zarazem. Dzięki niej człowiek zaczyna dzisiaj władać kosmosem, stworzył nieznane przedtem środki komunikacji, ale również przy jej użyciu człowiek, szczególnie w minionym stuleciu, dokonywał milionowych mordów, zniewalał umysły ludzkie i deptał godność drugiego człowieka. Technika jest dzisiaj powodem do dumy, ale i do oskarżen' ${ }^{2}$. Aby uzdrowić technikę konieczne jest chrześcijańskie spojrzenie na wszelką aktywność człowieka i otwarcie jej na przemieniającą moc Zmartwychwstania. Naukowcy chrześcijańscy mają w tym względzie szczególne zadanie.

\section{2. Technika a zmartwychwstanie}

Nie należy dyskwalifikować poszukiwań naukowych i odkryć przez nie osiąganych. Chodzi o wysiłek, aby te badania uczynić bardziej respektującymi rzeczywistość. Chrześcijanin powinien wymagać od nauki badań bardziej otwartych na Boga, a od techniki skuteczności bardziej podporządkowanej, zarówno człowiekowi, jak i niezbędnej przyjaźni pomiędzy człowiekiem a wszechświatem, ponieważ: „[...] jeżeli ziemia nie może być już uważana za Matkę, to niech przynajmniej będzie uważana za narzeczoną" ${ }^{93}$.

Fundamentem nauki i techniki, a tym samym kryterium jej oceny, powinien być człowiek. Tylko właściwa wiedza o człowieku może zapewnić właściwy stosunek do wszelkiej działalności człowieka, a szczególnie techniki. Aby poznać to, kim jest człowiek, trzeba sięgnąć do Objawienia

Tamże, s. 166.

9] Tamże, s. 167.

92 Zob. E. OZOROWSKI, Technika w' interpretacji filozoficzno - teologicznej, s. 79.

93 O. CLÉMENT, Questions sur l'homme, s. 167. 
biblijnego. Dopiero pełna wiedza o człowieku, filozoficzno - teologiczna pozwoli odpowiedzieć na pytania o sens aktywności technicznej. Wyłania się ona z relacji: człowiek - świat; cel - środki; wieczność - doczesnośćc $^{04}$. O. Clément nazywa tę relację "niezbędną przyjaźnią"95. Sama technika, jak w ogóle praca ludzka, jest dobrem. Używać jej natomiast można na dobre i na złe. Problem tkwi w człowieku, który technikę tworzy i z niej korzysta ${ }^{96}$.

Clément przestrzega przed nadużywaniem bogactw naturalnych i podkreśla, że nadużycie jest odwrotnością użycia. Człowiek, w szczególności chrześcijanin, powinien używać dóbr, ale jednocześnie współdziałać z Chrystusem Zmartwychwstałym przy przeobrażaniu świata. Chrześcijanin, człowiek Zmartwychwstania, powinien uczestniczyć w badaniach naukowych i promować dialog z ludźmi nauki. Powinien świadczyć o tym, że osoba ludzka $z$ jednej strony i wszystkie byty stworzone $z$ drugiej są nie do wyczerpania w badaniach naukowych ${ }^{97}$.

Wszelka aktywność człowieka powinna być nieodłącznie związana z wysiłkiem przeobrażania świata i wszechświata. Nie może się ono odbywać bez zaangażowania wiary, ponieważ rozum pozbawiony światła wiary błądzi i sam siebie może zgubić. Przyzwolenie wiary, jak pisze Jan Paweł II, ograniczające rozum i wolę, nie niszczy, ale doskonali zdolność samodzielnego myślenia człowieka wierzącego, który przyjmuje prawdy objawione $^{98}$. W człowieku - naukowcu wierzącym, przez niego, kosmos liturgiczny zbliża się do świata upadłego, który jest poddawany badaniom. W człowieku i przez człowieka światło Zmartwychwstania "rozprzestrzenia się od atomu do mgławicy", „kontemplacja natury" jest przedłużana w poszukiwaniach naukowych, a chrystyczna moc reintegracji sprawia, że „odpływają siły chaosu” i nastaje nowy świat - świat piękna i harmonii ${ }^{99}$.

Problem cywilizacji technicznej jest dzisiaj coraz bardziej problemem sensu i celowości. Cel ten i sens mogą ukazać się jedynie przez człowieka duchowego, oświeconego wiarą. Tylko czlowiek eucharystyczny, pisze Clément, może zrealizować integrację materii. Tylko taki człowiek, który ze wszechświata czyni „kościól”, a ze swego serca „ołtarz”, może przypomnieć nauce i technice świętość Ziemi i konieczność pokory i respektu wobec niej. Dlatego chrześcijanie, aby przeobrazić technikę, wszelki wysiłek człowieka w Zmartwychwstanie, powinni celebrować Paschę „w ich codziennym działaniu, w ich codziennych, ziemskich zajęciach"100.

94 E. OZOROWSKI, Technika w interpretacji filozoficzno-teologicznej, s. 80.

95 O. CLÉMENT, Questions sur l'homme, s. 167.

\% E. OZOROWSKI, Technika w interpretacji filozoficzno-teologicznej, s. 80.

97 O. CLÉMENT, Questions sur l'homme, s. 168.

98 JAN PAWEL II, Fides et ratio, $\mathrm{nr} 75$.

99 O. CLÉMENT, Questions sur l'homme, s. 168.

100 Tamże, s. 169. 
Dzisiejszy człowiek chce zamknąć i ujarzmić technikę dla własnych doznań, a w rzeczywistości sam staje się jej niewolnikiem. Technika może stać się przeciwnikiem człowieka wtedy, gdy np. mechanizacja pracy wypiera człowieka, odbierając mu wszelkie zadowolenie osobiste oraz podniety do działania twórczego i odpowiedzialności; gdy pozbawia zajęcia wielu zatrudnionych dotąd pracowników lub, na skutek przesadnej fascynacji maszyną, czyni człowieka swoim niewolnikiem ${ }^{101}$. W ten sposób człowiek jest kierowany przez technikę, zamiast nią kierować i prowadzić ją w kierunku Paschy, przyczyniając się do ogólnej poprawy bytu i radości każdego człowieka. Wysiłek człowieka nie może być skierowany tylko ku postępowi jako takiemu, bez uwzględnienia dobra człowieka.

Wszelkie dyscypliny ascetyczne - otwarcie na Ducha, powinny stawać się wspólne wszystkim ludziom i nadawać kierunek „wspólnemu dziełu” ludzi, tzn. wiedzy naukowej i możliwościom nauki. Trzeba, aby człowiek odnalazł świadomie świętość Ziemi i poprzez nią „miłość ojców, których ciałem jest ziemia i którzy spoczywają w niej jako «zarodki» Zmartwychwstania"102. Pisze Clément, że każdy postęp, który nie byłby skierowany na Zmartwychwstanie wszystkich i wszystkiego, nie byłby niczym innym jak tylko "następowaniem po sobie kolejnych morderców” ${ }^{103}$. Tylko religia uniwersalnego Zmartwychwstania może zjednoczyć, w wielkim sakramencie życia, podzielone sektory kultury i wiedzy naukowo - technicznej ${ }^{104}$.

\section{Zakończenie}

Celem niniejszego artykułu było przedstawienie nauki wschodnich Ojców Kościoła i współczesnych myślicieli prawosławnych, głównie $\mathrm{O}$. Clément, na temat związku człowieka z resztą świata stworzonego. Naukę tę przedstawiliśmy w powiązaniu $z$ katolickimi myślicielami i przedstawicielami hierarchii Kościoła takimi, jak Jan Paweł II, E. Ozorowski, i T. Špidlik.

Człowiek żyje w określonym czasie i przestrzeni na styku przeszłości i przyszłości. Żyje w czasie, ale wychylony jest ku nieskończoności; żyje na ziemi, ale wychylony jest ku całemu kosmosowi, z którym wiąże go wspólny początek i wspólne dążenie do wyzwolenia się od zła. Człowiek też jako ten, który reasumuje w sobie to, co widzialne i to, co niewidzialne ma, zgodnie z Bożym planem, udzielać siebie nie tylko innym lu-

\footnotetext{
101 Zob. E. OZOROWSKI, Technika w interpretacji filozoficzno-teologicznej, s. 79.

102 O. CLÉMENT, Questions sur l'homme, s. 170.

103 Tamże, s. 170.

104 Tamże, s. 171.
} 
dziom, ale i całemu kosmosowi. W człowieku aktualizuje się zespolenie boskości z ziemskością, dzięki czemu przez niego „może rozprzestrzeniać się łaska na cale stworzenie" ${ }^{\prime 105}$.

Wszechświat jest pierwszym objawieniem Boga, Jego wyrazem i miejscem dialogu człowieka $\mathrm{z}$ Bogiem ${ }^{106}$. Człowiek jest w centrum Bożego dzieła stworzenia i kondycja kosmosu zależy, w dużej mierze od kondycji człowieka. Bóg, który daje poznać siebie również przez stworzenia, pragnie, by człowiek naśladował Go w każdym możliwym aspekcie, dlatego też człowiek ma udział w kształtowaniu kosmosu. Człowiek został wezwany przez Boga, aby stworzeniom nadawał imię (por. Rdz 2, 19), by świadomie odkrywał ich znaczenie.

Dialog człowieka z Bogiem został zakłócony przez grzech pierworodny nazywany przez Ojców Kościoła prawdziwą "katastrofą kosmiczną". Za każdą niedoskonałość panującą w kosmosie odpowiedzialny jest człowiek, ponieważ to on w swej wolnej woli wybrał pozór dobra. Wybranie nawet mniejszego dobra rodzi niedoskonałość i powstaje "miejsce" na $z_{ł o}{ }^{107}$. W wolnej woli człowieka powstaje zaczątek zła, który jest wykorzystywany przez Szatana i jego sługi. Wszechświat, który przed grzechem pierworodnym był rajem dla człowieka, po grzechu jest przez niego wykorzystywany i niszczony w "drapieżnym utylitaryzmie". Im większa jest niedoskonałość dialogu człowieka z Bogiem, tym wyraźniej znika harmonia i piękno kosmosu. Im większy grzech człowieka (logikôs) i jego matowość (nieprzejrzystość) na Bożą łaskę, tym większy błąd w nadawaniu imion i odkrywaniu znaczenia (logoi) wszystkich rzeczy.

Bóg, jednak, nie pozbawił człowieka i całego wszechświata swojej opieki. Na Boży plan stworzenia nakłada się plan odkupienia i zbawienia. Człowiek, który wszelką władzę i moc otrzymał od Boga, może przemieniać wszechświat jedynie dzięki otwarciu się na przemieniająca moc Chrystusa - Boga Człowieka, Zbawiciela. Problem wszelkiej aktywności człowieka, często pozbawionej sensu i celowości, może być rozwiązany jedynie przez otwarcie się na Ducha. Tylko czlowiek "duchowy” będzie zdolny nadać właściwe imię wszystkim rzeczom i właściwy sens oraz cel wszelkiej ludzkiej aktywności.

105 J. APTACY, Antropologia Oliviera Clément, s. 142.

106 E. KOTKOWSKA, Pomyśleć świat jako catość wedlug śu: Grzegorza z Nyssy, s. 179.

107 Tamże, s. 179. 


\title{
Man and Nature in the Teaching of the Christian East
}

\author{
SUMMARY
}

This article speaks of the relation between man and the rest of the created world. This is a subject that is being taken up more and more frequently by ecologists, by philosophers and theologians.

Man is in relation with the universe above all because of their common beginning. For everything, human beings included, came into being "from nothing" (ex nihilo). Secondly: all of creation, even if to a different degree, is subject to the laws of limitations. Thirdly: all of the universe, that means also man living in it, is called to development and liberation from the burdening of evil, in order to participate in the freedom and glory of the children of God (cfr. Rom 8:21).

The subject of the relation of man with the rest of the created world was dear to the Fathers of the Church, especially in the East. The heritage of the Eastern Church Fathers has been taken up mainly by Orthodox theologians. But there are also Catholic theologians that take up the subject of the relation between man and the universe. Here one should name above all $\mathrm{K}$. Rahner, H.U. von Balthasar and, among Polish theologians: W. Hryniewicz.

Among the contemporary Orthodox theologians that speak of the relation between man and the universe, we find $O$. Clément. For him relations with God the Creator and Savior are of importance. Upon these relations depend other ones: with other people and with the universe. If one does not take this into consideration, one's knowledge of man himself would be incomplete.

Relations between man and the universe can be twofold: man can remain on the outside of reality which shows itself to his eyes or he can be inserted into this reality, which he shall observe as an organic all-embracing unity. Visible nature, as $\mathrm{O}$. Clément writes, is a book rich in content, which speaks of life on Earth and after death. It is only necessary to know how to make use of this book.

Man created in the "image and likeness" of God is marked by divinity and participates in the divine intellect and, by means of his body, is in relation with the material world. He concentrates in himself what is spiritual and what is material. All of the created universe can participate in divine "energies" only through man, who is "priest and caretaker" of the universe. It is the duty of man to read the first revelation (that is the world) and to "realize the ontological glorification of all things".

But man, because of original sin, has led to a true cosmic catastrophe, to a darkening of the modality of paradise and to the appearance of a new way of universal existence, marked by $\sin$. Man also ceased to understand the true world, the way God created it and sustains it in His glory. Creation, just as its Creator, does not thrust itself upon man, who sees the universe through the prism of his fall which in such a manner obscures and covers it, that he becomes more and more obdurated to the action of God. 
This universe, marked by sin can be transformed by man, but in Christ, God and Maximum Man. Man can properly guide the universe to the extent that he does so in union with God - Creator and Christ - Redeemer and Restorer.

This is the direction in which all of human activity should go: making use of the achievements of science and technology. Any progress that does not lead to the improvement and embellishment of the universe is nothing else but "the succession of one after another of consecutive murderers". All of human activity must be inseparably connected with the effort of the transformation and embellishment of the world and the universe. 